\title{
Food preferences of the sea urchin Diadema antillarum in Gran Canaria (Canary Islands, central-east Atlantic Ocean)
}

\author{
F. Tuya*, J.A. Martín, G.M. Reuss and A. Luque \\ Department of Biology, School of Marine Sciences, Universidad de Las Palmas de Gran Canaria, 35017, \\ Las Palmas de Gran Canaria, Canary Islands, Spain.*E-mail: ftuya@ciemar.ccbb.ulpgc.es
}

\begin{abstract}
Preferences of the sea urchin Diadema antillarum (Echinodermata: Echinoidea) feeding on five species of brown macroalgae (Padina pavonica, Dyctiota dychotoma, Cystoseira abies-marina, Lobophora variegata and Halopteris filicina) have been studied using caging field experiments on Gran Canaria Island during August to October 2000. Results of three assays of both single and multiple diet experiments rejected the null hypothesis that Diadema does not feed selectively on the five selected algal species. In the multiple diet assays, Diadema consumed an average of 68-98 $\mathrm{mg}$ algae $\mathrm{urchin}^{-1} \mathrm{~h}^{-1}$ and $4-120 \mathrm{mg}$ algae $\operatorname{urchin}^{-1} \mathrm{~h}^{-1}$ in the single diet experiments. On the basis of consumption, the five species of algae eaten can be divided into three groups. Thus Halopteris, Lobophora and Dyctiota were considered preferred algae, while Padina was considered an intermediate alga. Finally Cystoseira was significantly the less preferred and consumed seaweed in all sets of assays.
\end{abstract}

\section{INTRODUCTION}

Marine biodiversity has been decreasing in the coastal areas of the Canary Islands mainly due to the increase in fishing pressure over the past few decades as a direct effect of an increase in tourism and the human population (Aguilera et al., 1996). One feature of this reduced biodiversity is the demographic explosion in the infralittoral rocky zones of the sea urchin Diadema antillarum (Phillipi) (Aguilera et al., 1996; Barquín et al., 1999). This grazing species has exacerbated the deterioration of biodiversity along the Canarian Archipelago, by inducing the decline of the macroalgae populations. Diadema antillarum presents an anfiatlantic distribution, and their feeding preferences have been extensively studied along the Caribbean (Atkinson et al., 1973; Lawrence, 1975; Carpenter, 1981).

However, very little research has been undertaken in the central-east Atlantic to understand and assess the food preferences of this echinoid. In this study, we assess the feeding preferences of Diadema on five species of common brown seaweeds through the use of field caging experiments (single and multiple diets). The goals of this paper are: (1) to test the hypothesis, stated by several authors (e.g. Anderson \& Velimirov, 1982), that Diadema is not a selective grazer in the field, vs the alternative hypothesis that Diadema feeds selectively; and (2) to obtain a ranking of seaweed preferences and relate it to features of the studied seaweeds.

\section{MATERIALS AND METHODS}

\section{Cages and plates}

Preference assays were carried out using mesh cages $(0.5 \times 0.5 \times 0.5 \mathrm{~m})$, similar to those employed by Vadas et al. (1986). Cages were assembled using PVC cubic frames and covered with mesh $(10 \times 10 \mathrm{~mm})$ nylon netting. The bottom of the cages were open to the natural substrate but hemmed with mesh skirts, which were weighted with boulders to prevent the escape of sea urchins and to anchor the cage. We also used rectangular $(30 \times 30 \mathrm{~cm})$ concrete plates. A grid of 66 points was employed using elastic rope on each plate, to randomly locate and tie on seaweeds in each plate.

\section{Seaweed and urchin collection and maintenance}

Seaweed species were selected on the basis of abundance at this time within the Gando Bay Area (GBA) $\left(27^{\circ} 55^{\prime} \mathrm{N}\right.$ $\left.15^{\circ} 22^{\prime} \mathrm{W}\right)$, Gran Canaria Island. The five species were: Padina pavonica, Dyctiota dychotoma, Cystoseira abies-marina, Lobophora variegata and Halopteris filicina. Preliminary sampling (belt transects) allowed us: (1) to determine a number of five urchins per cage, on the basis of the mean density $\left(10\right.$ urchin $\mathrm{m}^{-2}$ ) of this echinoid along the grazed urchin barrens in the GBA; and (2) to fix the amounts of each seaweed used in these assays depending on the in situ relative abundance of each alga in relation to the others. Thus, each seaweed was provided in the following amounts: Padina (2-5 g), Dyctiota (3-7 g), Cystoseira (6-12 g), Lobophora (2-8 g) and Halopteris (10-20 g).

Seaweeds and urchins were collected using SCUBA diving before each experiment and held in seawater tanks until use. Only urchins with an individual test diameter of $50 \pm 5 \mathrm{~mm}$ were used to minimize size-specific differences in preference (Larson et al., 1980). Prior to each experiment, urchins were starved for a period of $24 \mathrm{~h}$ (Hay et al., 1986; Shunula \& Ndibalema, 1986) inside each cage.

\section{Measurement of seaweed consumption and feeding rate}

Wet mass of seaweeds was determined at the beginning and end $(48 \mathrm{~h})$ of each experiment, after spinning it in a 
salad spinner for $15 \mathrm{~s}$ (Hay et al., 1986). The difference between both measurements was defined as the feeding rate. Otherwise, seaweed consumption was defined as the percentage of weight gained/lost per seaweed $(\% \mathrm{Wt})$.

\section{Food preference}

All field-caging experiments were carried out in the GBA, during August-October 2000. Mesh cages and their corresponding concrete plates were deployed on a 4-5 m deep sandy bottom. Plates were transported from the boat to the bottom using mesh bags to avoid any perturbation of the attached algal material.

In single-diet experiments, 11 fragments $(\mathrm{N}=11$ replicates) of a single seaweed were randomly placed in the grid of a plate. Each plate was presented to five urchins inside a cage, in such a way that each urchin had an equal opportunity to graze on any one fragment. In multiple-diet experiments, six fragments $(\mathrm{N}=6)$ of each seaweed were randomly placed in each grid. Consequently 30 (6 fragments $\times 5$ species) fragments of algae were located in each plate and presented to five urchins. To allow for changes in algal biomass that were unrelated to consumption by urchins, controls were set up during each experiment. Controls (Cs) differed from others (Treatments $=\mathrm{Ts}$ ) only in that no urchin was included. In both Ts and Cs, the weight of the algae was determined at the beginning and the end of each experiment through the technique cited. Both sets of experiments (single and multiple diet) were replicated three times during three consecutive weeks to assess for any significant change in the feeding pattern not related to food preference. After each experiment, cages and plates were cleaned with freshwater and urchins removed.

\section{Data analysis}

Feeding rates were adjusted with Cs by subtracting (or adding to, as appropriate) the values obtained in Cs to the raw feeding rates, as Vadas (1977), Anderson \& Velimirov (1982), Hay et al. (1986) and Hay (1986) have shown.
Temporal replication of assays reduce the problem of spatial pseudoreplication of the experimental design, since spatial replication was logistically difficult.

For all sets of assays, Student's $t$-tests were conducted to check for significant changes in means from a zero value. The effects of urchin presence/absence (=Ts vs Cs), time (=number of assay, three assays for both single and multiple diet) and seaweed species on the seaweed consumption $(\% \mathrm{Wt})$ for the two groups of experiments (single and multiple diet) were analysed using a threefactor orthogonal analysis of variance (ANOVA). Urchin presence/absence and seaweed species were fixed factors, while time was considered random. The interpretation of interactions by Student-Newman-Keuls (SNK) test was used to identify the effect of the treatments. The assumptions of normality and homoscedasticity were tested by K-S and Levene's test, respectively. Since no transformation rendered homogeneous variances, the level of significance considered was 0.01 instead of 0.05 (Underwood, 1981). All the tests were realized by means of the SPSS ${ }^{\circledR}$ 10.0 statistical package.

\section{RESULTS}

\section{Diadema consumption}

Under the conditions of these caging experiments, Diadema consumed a range of 68-98 $\mathrm{mg}$ algae urchin $^{-1} \mathrm{~h}^{-1}$, after adjusting feeding rate values with controls in the multiple diet assays. Additionally, Diadema consumed between $4-120 \mathrm{mg}$ algae $\operatorname{urchin}^{-1} \mathrm{~h}^{-1}$ in the single diet experiments, depending on the seaweed species. Table 1 shows total feeding rates on each seaweed species and assay in both $\mathrm{Ts}_{\mathrm{s}}$ and $\mathrm{Cs}$, for single and multiple-diet experiments.

\section{Food preferences}

Figures 1 \& 2 show mean weight change $( \pm \mathrm{SE})$ of seaweeds in $T_{s}$ and $C_{s}$ for single- and multiple-diet experiments, respectively. Multiple diet assays have

Table 1. Total feeding rates for each seaweed ( $g$ algae assay ${ }^{-1}$ ) and assay ( $\mathrm{mg}_{\text {alga } \text { urchin }}{ }^{-1} \mathrm{~h}^{-1}$ ) in $\mathrm{Ts}$ and Cs, for both singleand multiple-diet experiments. A negative value indicates weight loss, while a positive value suggests that growth was greater than consumption.

\begin{tabular}{|c|c|c|c|c|c|c|c|c|c|c|c|c|}
\hline & \multicolumn{6}{|c|}{ Multiple diet } & \multicolumn{6}{|c|}{ Single diet } \\
\hline & \multicolumn{2}{|c|}{ Assay 1} & \multicolumn{2}{|c|}{ Assay 2} & \multicolumn{2}{|c|}{ Assay 3} & \multicolumn{2}{|c|}{ Assay 1} & \multicolumn{2}{|c|}{ Assay 2} & \multicolumn{2}{|c|}{ Assay 3} \\
\hline & $\mathrm{T}$ & $\mathrm{C}$ & $\mathrm{T}$ & $\mathrm{C}$ & $\mathrm{T}$ & $\mathrm{C}$ & $\mathrm{T}$ & $\mathrm{C}$ & $\mathrm{T}$ & $\mathrm{C}$ & $\mathrm{T}$ & $\mathrm{C}$ \\
\hline Halopteris & -12.15 & -0.51 & -15.19 & -0.43 & -14.33 & -0.62 & -17.47 & 7.46 & -17.92 & 11.37 & -12.75 & 5.26 \\
\hline Lobophora & -0.22 & -1.05 & -2.12 & -0.45 & -3.7 & -0.65 & -3.35 & 1.38 & -0.15 & 0.57 & -2.25 & 0.21 \\
\hline Cystoseira & -2.31 & 1.46 & 0.46 & 0.02 & -1.01 & 0.49 & -0.16 & 2.19 & -2.28 & 1.86 & -0.33 & 0.35 \\
\hline Dyctiota & -6.87 & -5.17 & -4.28 & 0.23 & -3.01 & 0.94 & -1.48 & 2.6 & -3.42 & 0.79 & -4.02 & 0.9 \\
\hline Padina & -0.94 & -0.87 & -1.66 & 0.56 & -1.08 & 0.24 & -4.25 & 0.78 & -0.75 & 0.39 & -1.4 & 0.31 \\
\hline $\begin{array}{l}\text { Total } \\
\qquad\left(\mathrm{g} \mathrm{alga}^{-1}\right) \\
\left.\text { assay }^{-1}\right)\end{array}$ & -22.49 & -6.14 & -22.79 & -0.07 & -23.13 & 0.4 & -26.39 & 14.41 & -24.52 & 14.98 & -20.75 & 7.03 \\
\hline $\begin{array}{l}\text { Total } \\
\qquad(\mathrm{mg} \text { alga } \\
\left.\text { urchin }^{-1} \mathrm{~h}^{-1}\right)\end{array}$ & -93.71 & -25.58 & -94.96 & -0.29 & -96.38 & 1.67 & -109.96 & 60.04 & -102.16 & 62.41 & -86.45 & 29.29 \\
\hline
\end{tabular}



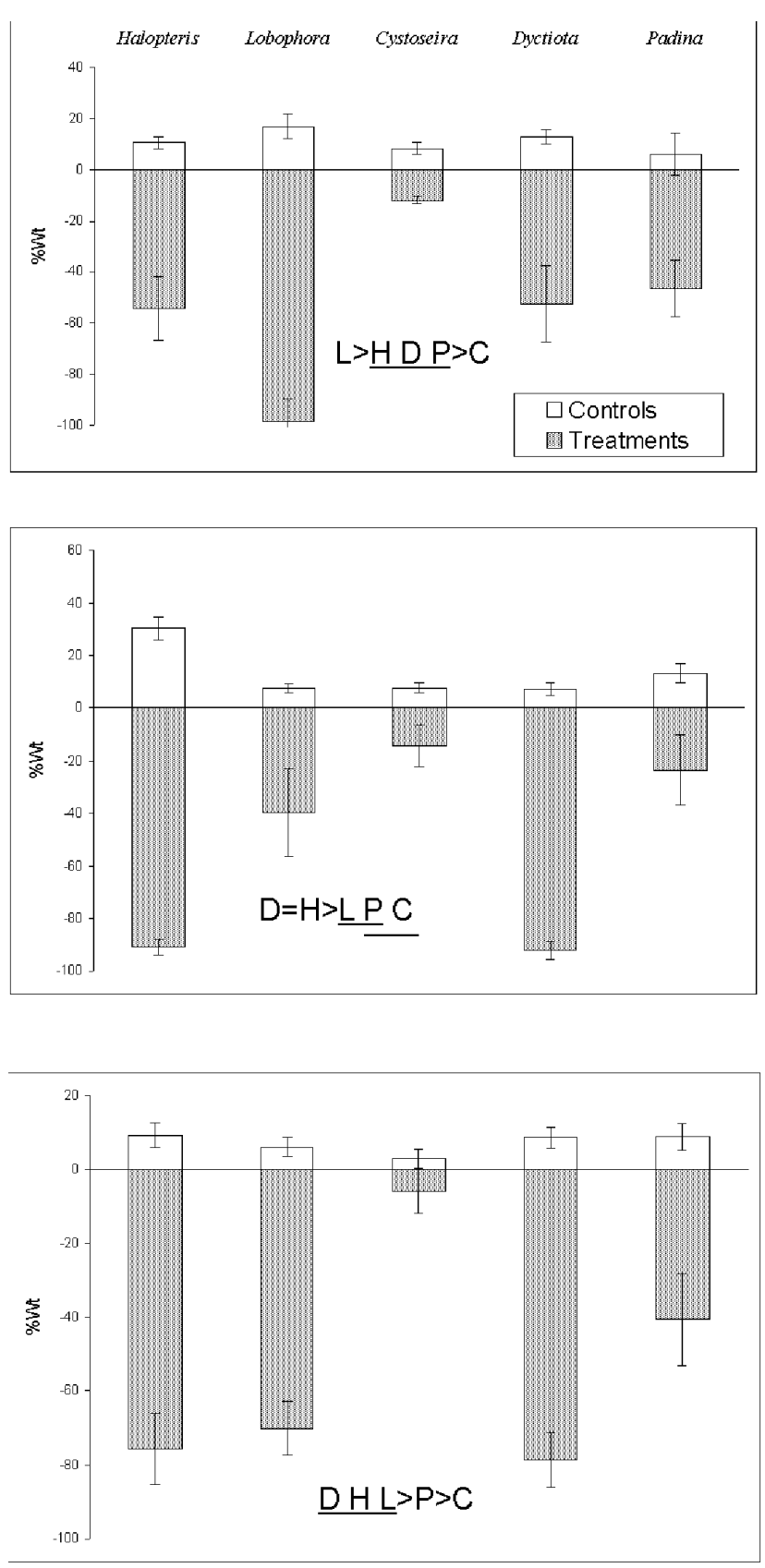

Figure 1. Rankings of seaweed consumption resulting from SNK tests and mean-weight change of seaweeds in Ts and Cs for single-diet experiments. Error bars represent SE of the means; ns, non significant change in means from a zero value as results of Student's $t$-test; C, Cystoseira; D, Dyctiota; H, Halopteris; L, Lobophora; P, Padina.

shown less temporal variability than single diet assays, since the term 'Ts vs Cs $\times$ Seaweed' has presented a significant interaction $(P<0.01)$ with the factor 'assay' (Ts vs $\mathrm{Cs} \times$ Seaweed $\times$ Assay, Table 2 ) in the ANOVA design for the single diet assays. While the factor 'assay' has not shown any significant interaction $(P>0.01$; Table 2) with the factors 'seaweed' and 'Ts vs Cs' for both groups of experiments. Furthermore and for both, the three-factor ANOVA has not detected significant differences $(P>0.01$; factor 'assay' in Table 2$)$ in mean consumption among the three sets of experiments carried out during successive weeks. However significant
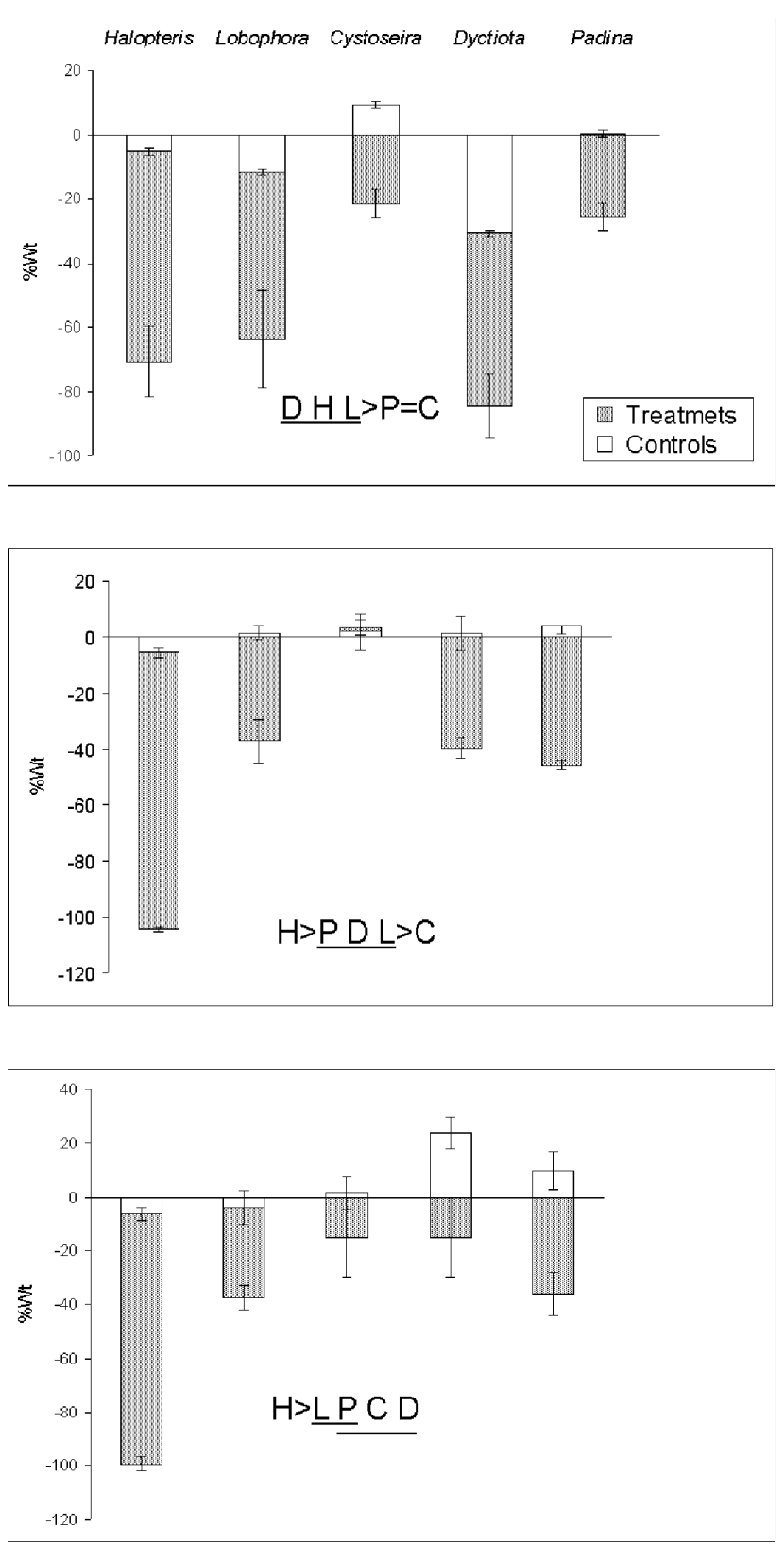

Figure 2. Rankings of seaweed consumption resulting from SNK tests and mean weight-change of seaweeds in Ts and Cs for multiple-diet experiments. Error bars represent SE of the means; ns, non significant change in means from a zero value as results of Student's $t$-test; C, Cystoseira; D, Dyctiota; H, Halopteris; L, Lobophora; P, Padina.

differences were detected for the factors 'seaweed' and 'Ts vs Cis' $(P>0.01$; Table 2).

Feeding patterns from single and multiple diet experiments were similar. Thus, Cystoseira was the least preferred seaweed in both groups of assays. Furthermore, Cystoseira was not significantly consumed in five of the six sets of experiments, as indicated by non-significant $t$-values (Figures 1 \& 2). Halopteris, Lobophora and Dyctiota were the most preferred species. Padina was not significantly consumed in two sets of the single-diet experiments (Figure 1). However, as the SNK tests showed (Figures 1 \& 2), the ranking of these seaweed species varied for each assay. Furthermore, estimated consumption of seaweeds was notably variable. Thus, only in three sets, a seaweed (Halopteris, twice in multiple diet and Lobophora in single 
Table 2. Results of three-way ANOVA conducted on the seaweed consumption for the two groups of assays (multiple-and singlediet).

\begin{tabular}{|c|c|c|c|c|c|}
\hline \multirow[b]{2}{*}{ Source of variation } & \multirow[b]{2}{*}{$\mathrm{df}$} & \multicolumn{2}{|c|}{ Multiple diet } & \multirow{2}{*}{$\begin{array}{c}\text { Single diet } \\
\text { MS }\end{array}$} & \multirow[b]{2}{*}{$\mathrm{F}$} \\
\hline & & MS & $\mathrm{F}$ & & \\
\hline Ts vs Cs & 1 & 70330.02 & $211.88 *$ & 309734.40 & $795.25 *$ \\
\hline Seaweed & 4 & 7504.42 & $22.60 *$ & 5411.88 & $13.89 *$ \\
\hline Assay & 2 & 831.04 & $0.605 \mathrm{~ns}$ & 357.10 & $3.414 \mathrm{~ns}$ \\
\hline Ts vs Cs $\times$ Seaweed & 4 & 4193.01 & $7.40 *$ & 7755.77 & $1.68 \mathrm{~ns}$ \\
\hline Ts vs Cs $\times$ Assay & 2 & 504.04 & $0.89 \mathrm{~ns}$ & 1600.63 & $0.34 \mathrm{~ns}$ \\
\hline Seaweed $\times$ Assay & 8 & 1546.16 & $2.73 \mathrm{~ns}$ & 3094.57 & $0.67 \mathrm{~ns}$ \\
\hline Ts vs Cs Seaweed $\times$ Assay & 8 & 566.28 & $1.70 \mathrm{~ns}$ & 4590.59 & $11.78 *$ \\
\hline \multirow[t]{2}{*}{ Residual } & 120 & 331.92 & & & \\
\hline & 180 & & & 389.48 & \\
\hline
\end{tabular}

*, $P<0.01 ;$ ns, non significant.

diet experiments) was the most significantly $(P<0.01)$ consumed seaweed.

Padina did not significantly change in weight in all the Cs for both single and multiple-diet experiments (non significant $t$-values, Figures 1 \& 2). Otherwise, all the seaweed species (excluding Halopteris) showed in some of the multiple-diet control sets a non-significant growth (Figure 2). Some species even showed a decrease in weight.

\section{DISCUSSION}

\section{Diadema consumption}

Feeding rates of Diadema antillarum in Gran Canaria Island have shown a range of values in single-diet assays greater than those observed for Diadema setosum in Tanzania (54-80 mg algae urchin $^{-1} \mathrm{~h}^{-1}$, Shunula \& Ndibalema, 1986) and those detected for Strongylocentrotus drobachienis in Maine (16-53 and 10-26 mg algae urchin ${ }^{-1}$ $\mathrm{h}^{-1}$, during summer and winter, respectively, Larson et al., 1980; and 2-43 mg algae urchin $^{-1} \mathrm{~h}^{-1}$, Prince \& LeBlanc, 1992). However the maximum observed value $(120 \mathrm{mg}$ algae urchin $^{-1} \mathrm{~h}^{-1}$ ) was lower than that detected for Arbacia punctulata in North Carolina (175 mg algae urchin $^{-1} h^{-1}$, Hay et al., 1986).

On the other hand the values observed in multiple-diet assays have been greater than those detected for S. drobachienis (1-19 and 1-15 $\mathrm{mg}$ algae $\operatorname{urchin}^{-1} \mathrm{~h}^{-1}$, during summer and winter, respectively, Larson et al., 1980; and 6-46 $\mathrm{mg}$ algae urchin $^{-1} \mathrm{~h}^{-1}$, Prince \& LeBlanc, 1992) and those analysed by Hay et al. (1986) for A. punctulata. Finally this range has shown lower values than those detected for D. setosum (450-585 mg algae $\operatorname{urchin}^{-1} \mathrm{~h}^{-1}$, Shunula \& Ndibalema, 1986).

\section{Food preferences}

This series of experiments has provided enough evidence to reject the null hypothesis stated. Diadema antillarum feeds selectively upon the five selected brown seaweed species of the Gran Canaria Island. Furthermore and contrary to the report of Prince \& LeBlanc (1992), this pattern remains constant in all multiple- and single-diet trials of this study. This finding is similar to the results obtained for D. antillarum by Atkinson et al. (1973) working in a tropical patch reef. However, as the ANOVA has shown, there has been a significant variability in the results of feeding preferences $(\% \mathrm{Wt})$ depending on the assay. As observed by Schiel (1982) the rankings of algal species were not consistent between the different assays of the two groups of experiments. Consequently, this fact reflects an important degree of randomness in the results of feeding preference experiments. As Underwood (1997) has considered, the lack of independence within the data in preference assays is responsible for this high variability, since independence is very logistically difficult to achieve.

Many studies with different sea urchin species have shown a high degree of food selectivity, whether foods were presented singly or in combination (e.g. Hay et al., 1986; Larson et al., 1980; Shunula \& Ndibalema, 1986). Nevertheless feeding preferences depend on grazing pressure and competition. Lawrence (1975) pointed out that grazing is selective under conditions of abundant food supply, but that selectivity disappears when grazing pressures become extreme. In our study, the number of urchins per cage was selected on the basis of the average density of this invertebrate along the GBA. Consequently D. antillarum behaves in the field as a selective feeder at its average density where algae are abundant. However future research should focus on the influence of competition and grazing pressure on the feeding preferences of this echinoid.

On the basis of consumption, the five species of algae used in this study can be divided into three groups, using an approach similar to that displayed by Anderson (1983). Halopteris, Lobophora and Dyctiota are considered to be preferred algae $(\% \mathrm{Wt} \sim 40-100 \%)$, Padina is considered an intermediate alga (Wt 20-50\%), and Cystoseira is the least preferred seaweed $(\mathrm{Wt}<20 \%$ ). Shunula \& Ndibalema (1986) working with Diadema setosum and Heliocidaris erythrogramma also found a similar pattern. They found that Cystoseira was eaten at an average of $8 \% \mathrm{Wt}$ by Diadema and $5 \% \mathrm{Wt}$ by Heliocidaris. Furthermore the study of Larson et al. (1980) showed a low preference of this alga by the sea urchin Strongylocentrotus droebachiensis. This avoidance is attributable to the rather coarse and tough body of this alga (structural factors), as well as to 
the presence of polyphenols (chemical factor). Several studies (e.g. Winter \& Estes, 1992; Knoess \& Glombitza, 1993) have shown the presence of these compounds in algae of the genus Cystoseira. These features are believed to act as defences against herbivores (Shunula \& Ndibalema, 1986).

It has been observed that Cystoseira forms monospecific extensive beds along subtidal environments off Gran Canaria. This could be attributable to the presence of the defences against marine herbivores cited above and consequently low preference of this alga by sea urchins, as our study has shown.

We thank Gando Military Base (Servicio Marítimo) for the logistical support of this study. We also thank Fernando Marián and Sergio Armas for their assistance in the field and photographic work. We gratefully thank Dr P. Sánchez for the refereeing of this paper.

\section{REFERENCES}

Aguilera, F., Brito, A., Castilla, C., Díaz, A., Fdez-Palacios, J.M., Rodríguez, A., Sabaté, F. \& Sánchez, J., 1996. Canarias: Economía, Ecología y Medio Ambiente. Islas Canarias: Francisco Lemus.

Anderson, R.J., 1983. An experimental investigation of algal feeding preferences in the sea urchin Parechinus angulosis Leske. Proceedings of the Fifth National Oceanographic Symposium. Council for Scientific and Industrial Resources (South Africa), 11 pp.

Anderson, R.J. \& Velimirov, B., 1982. An experimental investigation of the palatability of kelp bed algae to the sea urchin Parechinus angulosus Leske. P.S.Z.N.I. Marine Ecology, 3, 357-373.

Atkinson, C., Hopley, S., Mendelsohn, L. \& Yacowitz, S., 1973. Special Publications No. 2, West Indies Laboratory (ed. J.G. Odgen et al.), pp. 65-80. St Croix: West Indies Laboratory.

Barquín, J., Falcón, J.M. \& Brito, A., 1999. Presente y futuro de las Reservas Marinas de Canarias. Gobierno de Canarias: WWF.

Carpenter, R.C., 1981. Grazing by Diadema antillarum and its effects on the benthic algal community. Fournal of Marine Resources, 39, 749-765.

Hay, M.E., 1986. Associational plant defenses and the maintenance of species diversity: turning competitors into accomplices. American Naturalist, 128, 617-641.
Hay, M.E., Lee, R.R. \& Guieb, R.A., 1986. Food preference and chemotaxis in the sea urchin Arbacia punctulata (Lamarck) Philippi. Journal of Experimental Marine Biology Ecology, 96, 147-143.

Knoess, W. \& Glombitza, K.W., 1993. A phenolsulphatase from the marine brown alga Cystoseira tamaiscifolia. Phytochemistry, 32, 1119-1123.

Larson, B.R., Vadas R.L. \& Keser, M., 1980. Feeding and nutritional ecology of the sea urchin Strongylocentrotus droebachiensis in Maine, USA. Marine Biology, 59, 49-62.

Lawrence, J.M., 1975. On the relationships between marine plants and sea urchins. Oceanography and Marine Biology. Annual Revierw, 13, 213-286.

Prince, J.S. \& LeBlanc, W.G., 1992. Comparative feeding preference of Strongylocentrotus droebachiensis (Echinoidea) for the invasive seaweed Codium fragile ssp. tomentosoiodes (Chlorophyceae) and four other seaweeds. Marine Biology, 113, 159-163.

Schiel, D.R., 1982. Selective feeding by the equinoid, Evechinus chloroticus, and the removal of plants from subtidal stands in northern New Zealand. Oecologia, 54, 379-388.

Shunula, J.P. \& Ndibalema, V., 1986. Grazing preferences of Diadema setosum and Heliocidaris erythrogramma (Equinoderms) on an assortment of marine algae. Aquatic Botany, 25, 91-95.

Underwood, A.J., 1981. Techniques of analysis of variance in experimental marine biology and ecology. Oceanography and Marine Biology. Annual Revierw, 19, 513-605.

Underwood, A.J., 1997. Experiments in ecology: their logical design and interpretation using Analysis of Variance. Cambridge: Cambridge University Press.

Vadas, R.L., 1977. Preferential feeding: an optimization strategy in sea urchins. Ecological Monographs, 47, 337-371.

Vadas, R.L., Elner, R.W., Garwood, P.E. \& Babb, I.G., 1986. Experimental evaluation of aggregation behavior in the sea urchin Strongylocentrotus droebachiensis. Marine Biology, 90, 433-448.

Winter, F.C. \& Estes, J.A., 1992. Experimental evidence for the effects of polyphenolic compounds from Dictyoneurum californicum Ruprech (Phaeophyta: Laminaridae) in feeding rate and growth in the red abalone Haliotis rufescens Swainson. Journal of Experimental Marine Biology and Ecology, 155, 263-277.

Submitted 8 Fanuary 2001. Accepted 19 Fuly 2001. 